\title{
SUBSURFACE FLUX ADJUSTMENTS AND SPELEOGENESIS AS INFERRED FROM SEDIMENT TRAPS IN MAJOR LEBANESE CAVE SYSTEMS
}

\author{
REKONSTRUKCIJA PALEOHIDROLOŠKIH IN SPELEOGENETSKIH \\ RAZMER V IZBRANIH LIBANONSKIH JAMAH NA OSNOVI \\ RAZISKAV JAMSKIH SEDIMENTOV
}

\author{
Carole NEHME ${ }^{1,2,3 *}$, Stephane JAILLET ${ }^{1,3}$, Jean-Jacques DELANNOY ${ }^{1,3}$, Jocelyne ADJIZIAN-GERARD ${ }^{1,2}$, \\ Mazen ARZOUNI ${ }^{3}$, Rita STEPHAN ${ }^{3}$ \& Tony COMATY ${ }^{3}$.
}

\begin{abstract}
UDC 551.435.84(569.3)

Carole Nehme, Stephane Jaillet, Jean-Jacques Delannoy, Jocelyne Adjizian-Gerard, Mazen Arzouni, Rita Stephan \& Tony Comaty: Subsurface flux adjustments and speleogenesis as inferred from sediment traps in major Lebanese cave systems Caves are natural sediments traps that enclose several types of allochtonous and authoctonous deposits. Study of sediments in caves help to reconstitute the hydrological functioning of caves. In Lebanon, Kessarat and Jeita horizontal caves comprise sediments traps related to collapse and/or to passages enlargements with new passages formed during the alluviation process. A speleogenic study combined with the grain-size analysis of the sedimentary sequence in the Junction Chamber (Kassarat cave) and in the Entrance Gallery (Jeita lower cave) helped to identify several stages of sediment deposition and to define types of paleoflow adjustments during and after the ceiling collapse. In this paper, we discuss the control of cave conduits on several processes: i) the flow dynamic adjustments; ii) the spatial and temporal distribution of deposits in the cave systems and, iii) the magnitude of the environmental signal recorded in sedimentary sequences. The study highlights the importance to consider the geomorphological context of sediments traps when interpreting the evolution of subsurface flows and when relating sediment inputs in caves to external environmental changes.
\end{abstract}

Keywords: cave sediments, threshold effect, flow velocity, Lebanon.
Izvleček

UDK 551.435.84(569.3)

Carole Nehme, Stephane Jaillet, Jean-Jacques Delannoy, Jocelyne Adjizian-Gerard, Mazen Arzouni, Rita Stephan \& Tony Comaty: Rekonstrukcija paleohirdoloških in speleogenetskih razmer $v$ izbranih Libanonskih jamah na osnovi raziskav jamskih sedimentov

Jame so pasti za alohtone in avtohtone sedimente. $\mathrm{Na}$ osnovi študij jamskih sedimentov lahko rekonstruiramo paleohidrološke razmere v jamah. Sedimenti v jamah Kessarat in Jeita $v$ Libanonu so povezani s podiranjem in/ali razvojem jamskih kanalov s procesom aluvijacije. Speleogenetska študija in analiza velikosti zrn v sedimentnem zaporedju v Dvorani povezave (Junction Chamber) $\mathrm{v}$ jami Kassarat in Vhodnem rovu spodnje jame Jeita, sta omogočili identifikacijo več faz odlaganja sedimentov in načinov prilagoditve paleotoka na podiranje jamskega stropa. $\mathrm{V}$ članku obravnavamo vpliv geometrije jamskih kanalov na več procesov: i) dinamično prilagoditev toka; ii) prostorsko in časovno porazdelitev jamskih sedimentov in iii) velikost okoljskega signala zabeleženega $\mathrm{v}$ jamskih sedimentih. Pri tem poudarimo pomen upoštevanja geomorfološkega konteksta pri interpretaciji razvoja podzemnega toka in pri študiji dotoka sedimentov $\mathrm{v}$ jame $\mathrm{v}$ odvisnosti od zunanjih okoljskih sprememb.

Ključne besede: jamski sediment, učinek praga, hitrost toka, Jeita, Libanon.

\footnotetext{
${ }^{1}$ EDYTEM UMR 5204-CNRS, Université de Savoie, le Bourget du Lac, France.

${ }^{2}$ Département de géographie, Université Saint-Joseph de Beyrouth, Lebanon.

${ }^{3}$ Association Libanaise d'Etudes Spéléologique (ALES), Mansourieh, Lebanon.

* Corresponding author: e-mail: Carole.nehme@univ-smb.fr
}

Received/Prejeto: 05.11.2014 


\section{1 - INTRODUCTION}

Cave sediments have been investigated in the last two decades using several new techniques (e.g.: sedimentary profile and grain-size anlysis, paleomagnetism, morphoscopy and mineralogy, ERT profile). Some of these techniques are combined in a multidisciplinary approach to better address new inquiries in various fields, such as: anthropolgy (Burger et al. 2008); paleoenvironment (Bull 1980; Polk et al. 2007) and paleotopography reconstructions (Farrant et al. 1995; Granger et al. 2001; Zupan Hajna et al. 2008; Delannoy et al. 2009; Puscas et al. 2010); paleoclimatology (Quinif 2006); speleogenesis and karst studies (Sbai et al. 1995; Hausselmann et al. 2010, Martini et al. 2011); natural hazards (De Waele et al. 2011). In the field of karst studies, caves are often considered as sediments traps (Sweeting 1972; Ford and Williams 2007). Studies of cave sediment help in reconstituting a temporary phase of the cave lifecycle (Farrant and Smart 2011). When completing the speleogenesis scheme of cave systems, the hydrological functioning of cave water influx and deposit sequences are rebuilt within the alluviation (White 1988) or a paragenesis context (Renault 1968).

Sediment storage in caves involves a wide range of clastic deposits (Bogli 1980) and depends on wa- ter influxes coming from stream-flows and drip-water over a long period of time. Sediment accumulation occurs when the rate of sediment input exceeds sediment transport through the system (Farrant and Smart 2011). This leads usually to a decrease of water influx energy and sediment alluviation. Sedimentary analysis indicate that changes in stream power is generally due to adjustments of the hydraulic dynamics of influx in response to regional and external effects such as base level fluctuations (Farrant et al. 1995; Jaillet 2005) near adjacent rivers or extreme flood events at the surface in response to external climate conditions (Sanderson 1977; Gillieson 1986).

Nevertheless, water influxes are confined to certain conduit sizes (White 2007) when infiltrated to subsurface karst systems. We can consider therefore, that deposit influx into caves systems and alluviation is highly localized. It depends on passage morphology that creates thresholds in the cave system (Lignier et al. 2012), presence of a form of blockage (White and White 1969; Jameson 1991) or located near resurgence or close to the surface (White 2007).

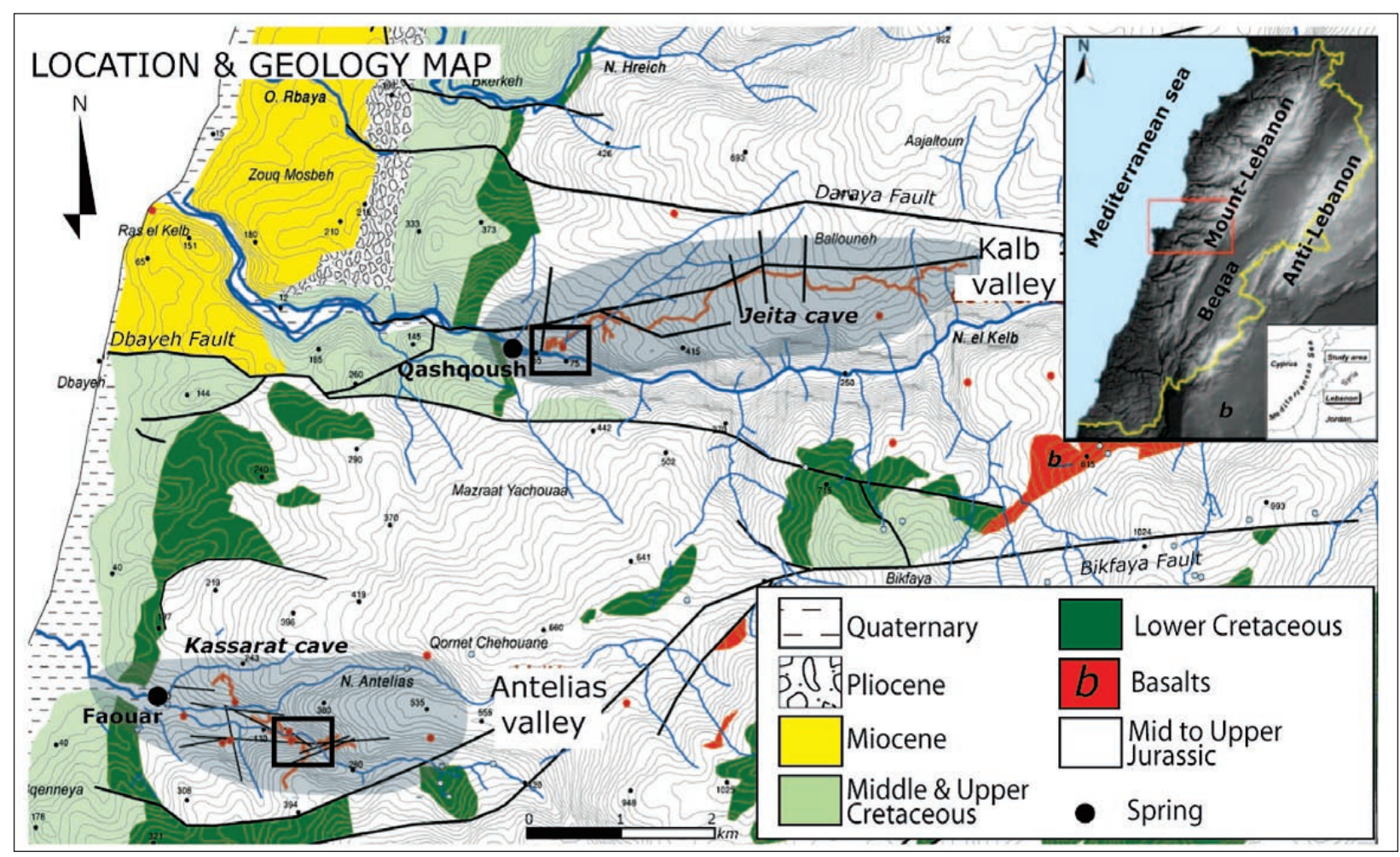

Fig. 1: The general geology map of the studied area shows the development of both Kassarat and Jeita cave in the Jurassic limestone (Geological map in Dubertret L. 1951, plotted on a DEM model: CMES/Spot Image (02012). Small black boxes indicate the location of both study sites in the Junction Chamber (Kassarat Cave) and the entrance gallery (Jeita lower Cave). 
Grain-size and sediment facies analysis help reveal the depositional history of sediments traps when clastic materials are available usually in horizontal or low gradient conduits (Ford and Williams 2007) and when they are not flushed out by latter water influx. Though, accumulation process can be relatively recent in the lifecycle of cave systems (Saswosky 2007). The presence of flowstone or quartz in deposit sequences can provide dating materials to set a model age for the deposition process (Bosak 2003; Quinif 2006). Conversely, it is more difficult to reconstitute, on both spatial and time scales, the formation of recent cave conduits when deposits and dating materials are not available. The only mean to study the formation of new conduits is when they are related synchronously to nearby sediment traps.

Recent studies in several passages $(4 \mathrm{~km})$ of Jeita cave $(10.06 \mathrm{~km})$ and Kassarat $(4.6 \mathrm{~km})$ cave (Nehme et al. 2012; 2013a), located respectively along Kalb and Antelias valleys in central Mount-Lebanon, helped to define the speleogenesis phases of both sites. Both caves are mutli-level systems of galleries with an underground river flooding in the lower levels (Hakim 1975; Hakim and Karkabi 1988). Both systems enclose several active and relict conduits where sediment accumulation is localized in preferential areas, especially behind collapse. In both systems, alluviation was identified as relatively recent processes that occurred in the final speleogenetic stages (Nehme 2013a). Ceiling collapse in both Jeita and Kassarat caves caused local hydrodynamic adjustments leading to alluviation up to several meters height. New adjacent conduits were formed to contain the water flows in response to the cieiling collapse and the alluviation.

The purpose of our work is to better describe the deposition process, both spatially and temporally, in the entrance part of Jeita lower Cave and in the Junction Chamber of Kassarat Cave. The description of the sediment profiles and the analysis of the mode of sediment deposition (velocity, discharge and type of motion) combined with the speleogenetic study helped to define the stages of the sediment deposition dynamics in both sites, during and after the ceiling collapse. The analysis of both sediments traps invokes several points of discussion: i) the definition of the mode of hydrodynamic adjustments started or increased by the collapse, ii) the spatial and temporal variability of the deposition process, along with the formation of new passages and, iii) the effect of cave conduits and threshold control on the environmental signal recorded in sedimentary sequences.

\section{2 - SETTINGS}

\subsection{LOCATION AND GEOLOGY}

Mount Lebanon is a mountainous ridge that borders the Eastern Mediterranean Sea. The main landscape consists of high plateaus reaching 3,088 m altitude entrenched by deep valleys. Fluvial streams run on a steep gradient and reach the Mediterranean Sea coast in less than $30 \mathrm{~km}$ distance. The coastline areas formed by steep dipping Cretaceous rocks separate the highly karstified Jurassic unit from the Mediterranean Sea and is considered to be an acquiclude to the flow circulation in Jurassic aquifers.

The Mount Lebanon is mainly formed by $4 \mathrm{~km}$ in thickness of Jurassic to Neogene limestone, sandstone and shale (e.g. Fig. 1). Jurassic rocks include around $1,400 \mathrm{~m}$ of limestone and dolomite grouped in the Kesrouane, Bhannes, Bikfaya and Salima formations (Dubertret 1945; Walley 2001). These extensively fractured rocks were subaerially exposed (Renouard 1955; Nader 2000) and karstificated probable during the late Jurassic (Mouty 2000) and early Cretaceous. An early phase of karstification is attributed to the late Jurassic to early Cretaceous period (Nader and Swennen 2004; Nader
2011). Cretaceous rocks comprises mainly up to $300 \mathrm{~m}$ of Neocomian to Barremian sandstone (Chouf Formation), $600 \mathrm{~m}$ of cenomanian limestone and dolomites (Sannine formation) and $800 \mathrm{~m}$ of Turonian to Senonian limestone (Maameltein Formation and Chekka formations). Cretaceous rocks covers significant parts of Jurassic limestone in central Lebanon. Neogene rocks comprises up to $300 \mathrm{~m}$ of Miocene limestone and 250 to 400 of Pliocene conglomerates. Miocene rocks are located along the coast and in the inland Beqaa valley. Coastal facies are exposed in Saida, Nahr el-Kalb and Jabal Turbol areas (Walley 1997) and were deposited unconformly on the sub-vertical beds of the Cretaceous sequence. Pliocene conglomerates reaches $200 \mathrm{~m}$ in the Kalb valley (Homberg et al., 2010) with deposits covering the Miocene sequence (Bou Jaoudeh 1999).

In early Miocene, the Levant coastal area and the Lebanese mesoscale structure became emergent. During the Mid-Miocene, the uplift of Mount Lebanon is related to the opening of the Red Sea and the Dead Sea Fault System activity (Bayer et al. 1988; Markis and Rihm 1991). 


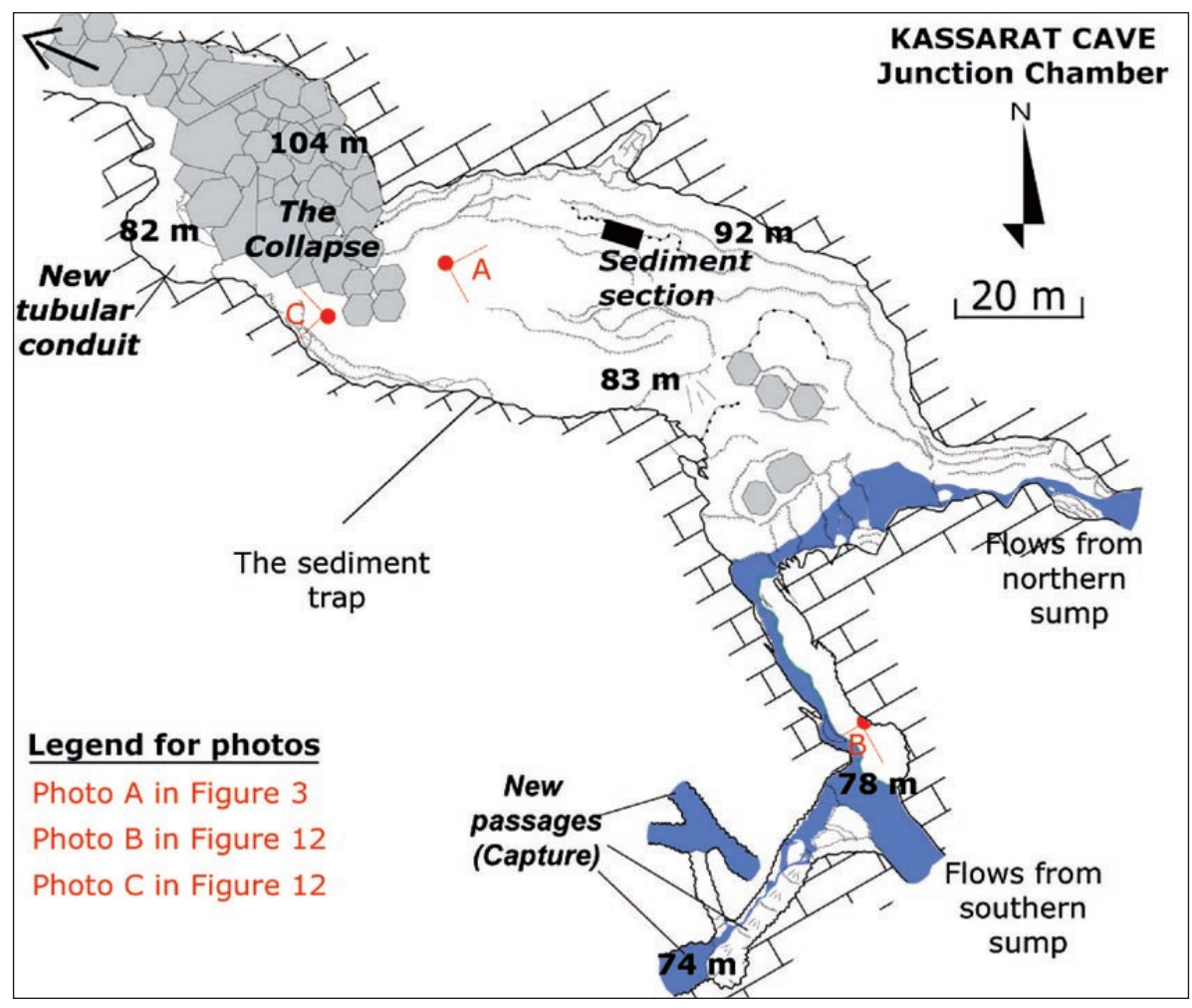

Fig. 2: The map of the Junction Chamber shows the ceiling collapse sector, the sediment trap and the new conduits (Map in Karanouh et al., 2004). Elevations (a.s.l.) are also indicated as well as the sediment section. Different photos with the corresponded figures are shown in the legend.

Around 5-6 Ma, a second rifting phase (Garfunkel 1989; 1998) of the Red Sea together with transpression across the Lebanese Restraining Bend enhanced Mount Lebanon uplift (Walley 2001).

\subsection{CLIMATE AND HYDROGEOLOGY}

Lebanon is characterized by a Mediterranean climate close to the arid/semi-arid climate boundary in southern Levant region. The average annual precipitation at the Jeita cave site today is around $1000 \mathrm{~mm}$ (Edgell 1997). The climate is seasonal, with rainy winters (between November and February) and dry, relatively hot summers (usually the period from May to October).

At the western edge of Mount Lebanon and near to the coast, the Jurassic limestone rocks host deep aquifers with a general East-West flow direction. The Cretaceous sequence of sandstone, marl and limestone units is considered herein as an aquiclude to the circulation of the subsurface water confining the structure-controlled karst systems in the Jurassic aquifer. The multilevel cave systems in the Jurassic unit comprise relict horizontal pattern of passages at several altitudes and present water table caves (Gabrovšek et al. 2014). The lowest active levels host underground rivers that feed karstic springs located at the aquiclude. Fouar spring in Antelias valley is at $30 \mathrm{~m}$ a.s.l. and has a discharge of 0.5 to $3 \mathrm{~m}^{3} / \mathrm{s}$ (Labaky 2005). In Kalb valley, the lowest karst outlet is Qashqoush spring at $46 \mathrm{~m}$ a.s.l. Jeita Spring is at $60 \mathrm{~m}$ a.s.l. and has a discharge of 1 to $25 \mathrm{~m}^{3} / \mathrm{s}$ (Doummar 2012). Dye-tracing experiments in each valley (Labaky 1998; Doummar 2012) showed a direct connection between underground flow of Kassarat and Jeita Caves to the lower karstic springs. The area between 30 and $60 \mathrm{~m}$ a.s.l. in both valleys constitutes the epiphreatic zone (Nehme 2013) of the karst system where significant water recharge during the wet season regularly floods small conduits and sumps. In Antelias valley, springs located between 30 and $60 \mathrm{~m}$ a.s.l. are temporarily active (Labaky 2005).

\subsection{CAVE DESCRIPTION AND STUDY SITES}

The investigated study area is the downstream part of Antelias and Kalb canyons, whose caves comprise more than $15.4 \mathrm{~km}$ of karst conduits (Abdul-Nour 2004). The major caves are Kassarat, Nabaa el-Chataouieh, 22 April, Bear, el-Dahr and Kanaan in Antelias Valley, Jeita and Qashqoush in Kalb valley. Some multi-level cave systems comprise abandoned and active galleries with a morphological connection between levels (e.g. Jeita, Kassarat caves). The investigated caves in Antelias and Kalb valleys are located mainly in Jurassic dolomitic limestone and very close to the aquiclude.

The Kassarat Cave $\left(33^{\circ} 54^{\prime} 38.00^{\prime \prime N}\right.$; 3536'30.88"E, entrance: $60 \mathrm{~m}$ a.s.l.) in Nabay area is the largest multilevel subsurface network in Antelias valley, with $4.6 \mathrm{~km}$ 


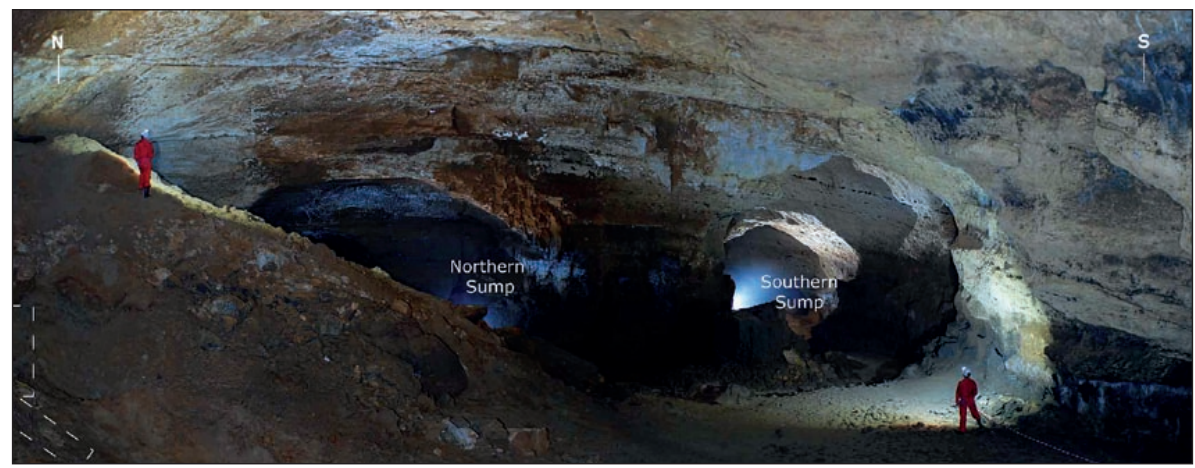

Fig. 3: The photo describes the location of the sedimentary sequence in the Junction Chamber. The horizontal level marks the top of the deposit sequence at 92 $m$ a.s.l. The studied sediment sections are indicated with dashed white line.

of passages (Karanouh et al. 2004; Metni and Nader 2005). The cave main axis generally trends East-West. The network system comprises a canyon that connects the lower level (around $60 \mathrm{~m}$ a.s.l.) to several higher galleries (Presidents and Dry galleries), above $90 \mathrm{~m}$ a.s.l. In the head part of Kassarat Cave system, two main galleries connect the northern and the southern sumps to the main canyon. Both sumps feed the Kassarat Underground River, which is drained through the main canyon at an average altitude of $64 \mathrm{~m}$ a.s.l. Underground flow runs on rocky river bed and transits then through the major sump (57 $\mathrm{m}$ a.s.l.) to join the Fouar Spring (30 m a.s.1.) (Hakim and Karkabi 1988; Labaky 2005). The Junction Chamber connects both sumps to the main canyon. It is one of the largest chambers in the cave and extends about $90 \mathrm{~m}$ in length (Nehme 2013c). It comprises: i) the Collapse area with about $35 \mathrm{~m}$ height located in a densely faulted area; ii) the sediment sector of $10 \mathrm{~m}$ height (e.g. Fig. 2). The thickness of deposits decreases gradually towards the southern sump. Presently, water flows coming from both sumps are diverted to a narrow passage (capture), located in the southeastern part of the Chamber. The site is unique in Kassarat cave and was chosen since it comprises large amount and diverse types of deposits, which were preserved by the ceiling collapse. The formation of new elliptical and capture conduits (e.g. Fig. 3) is also closely related to the sediment trap of the Junction Chamber.

In Kalb valley, the Jeita cave $\left(33^{\circ} 56^{\prime} 35.68^{\prime \prime} \mathrm{N}\right.$; $35^{\circ} 38^{\prime} 48.60^{\prime \prime E}$, entrance: $98 \mathrm{~m}$ ) is known to be the longest cave in Lebanon (Karkabi 1990). Located on the northern flank of Kalb valley, the cave is a multi-level system of dry and active galleries more than $10 \mathrm{~km}$ long in the Middle Jurassic limestones. In the 1950s, a part of the Jeita cave system was transformed into a touristic cave. A tunnel was dug at the entrance level of $98 \mathrm{~m}$ leading to the inactive galleries and a passage was widened at the lower entrance at $73 \mathrm{~m}$ making the lower active galleries more accessible to tourists. Jeita River flows through a series of rapids and wide chambers with collapsed

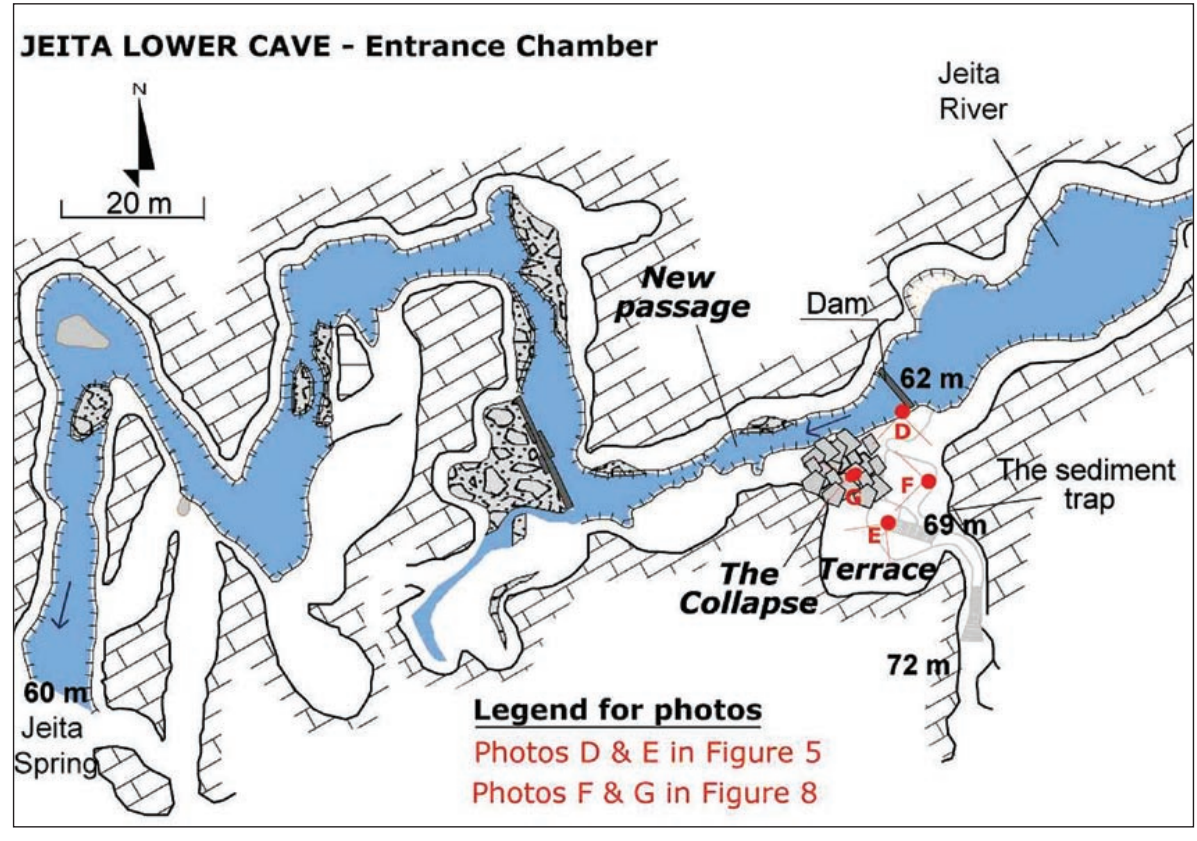

Fig. 4: The map of the Entrance Chamber (Lower level) shows the ceiling collapse sector, the sediment trap and the new conduits (Map in Karkabi et al., 1960). Elevations (a.s.l.) are also indicated. The location of different photos is indicated with their corresponded figures shown in the legend. 


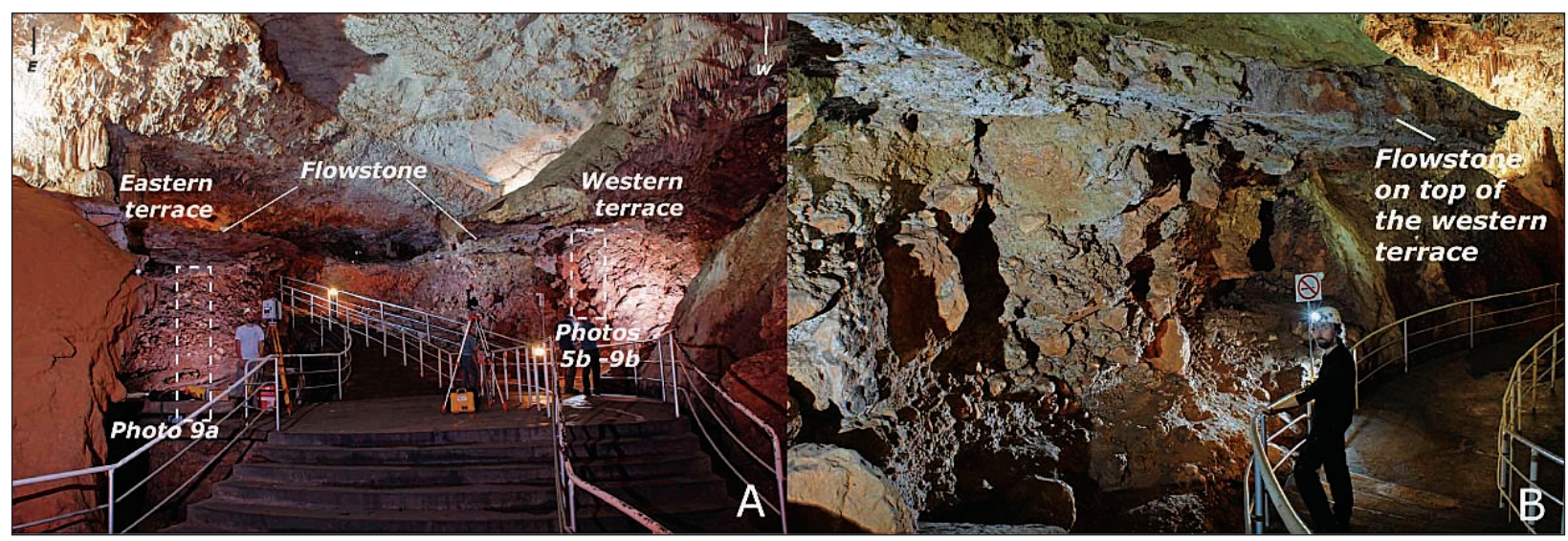

Fig. 5: The photo (A) shows a general view of the deposit sequence in the Entrance Gallery (Jeita lower Cave). Photos detailing the sediment sequence are indicated as Photos $9 A, 5 B$ and $9 B$ and located respectively in Figs. 5 and 9. A thick flowstone level (B) seals the deposit sequence of the fluvial terraces. (Photos by Jaillet $S$.)

blocks, sand and clay deposits, and joins the Kalb River at $60 \mathrm{~m}$ a.s.l. A $75 \mathrm{~m}$ deep canyon connects the inactive cave levels with lower active galleries where flow runs on the river bedrock.

The wide chambers of Jeita active cave are developed mainly along major local faults and considered to be important sediment traps comprising a wide range of clastic materials (silt particles to large pebbles). One of the main sediment traps is located at the entrance of the Jeita lower level and very close to the surface (e.g. Fig. 4). The section is currently exposed with $12 \mathrm{~m}$ height (e.g. Fig. 5). The torrential regime of Jeita River had left no preserved sediment section associated with a ceiling collapse along the river path. The only preserved section is located at the Entrance Chamber and comprises deposits coming from the inner Jeita River and from the Kalb River. The spatial configuration of the chamber with its enlarged southern side (e.g. Fig. 4) along with the ceiling collapse in the northern side functioned as a trap to the deposits. The stratigraphy combined with the geomorphological analysis of the Chamber helped to identified the corresponded levels deposited by Jeita and by Kalb Rivers and those deposited before and during the ceiling collapse.

\section{3 - METHODS}

The methodology is descried herein as a combination of several techniques used to compile data at different scales: i) the geomorphological mapping and sections in both the Entrance Gallery of Jeita lower level and the Junction Chamber of Kassarat cave, ii) description, sampling and analysis of a sediment section in both caves.

The fieldwork conducted in the study area investigated former cave surveys that were completed in Jeita (Karkabi 1963) and Kassarat (B.T.D. maps; Karanouh et al. 2004) Caves. Additional detailed cave mapping was also performed in the Junction Chamber (Kassarat cave) and in the Entrance Chamber (Jeita lower level). Topographic survey was performed also according to the speleological method (Grossenbacher 1991) using a cave compass, clinometer and laser-meter. This has implied the recompilation of all field survey data and the digitalization of drawings with the aim of obtaining a complete and detailed topographical map for each investigated site. Geomorphological surveys and detailed cross-sections were then undertaken in both sites. Observations of cave forms and deposits and the analysis of their spatial variability defined the main processes in the site genesis. The morphogenesis scenarios of both sediments traps are proposed using a relative chronology approach.

The sediment section of the Junction Chamber in Kassarat cave is $6.45 \mathrm{~m}$ long. 50 layers (50 to $100 \mathrm{~g}$ ) were identified and described. Morphoscopy and morphometry analysis were completed using Olympus U-PMTV microscope and grain size analyses were completed using MASTER SIZER S 2.19 after the sieving of samples to 800 $\mu \mathrm{m}$. Statistical analysis helped to produce C/M Passega schemes that propose a depositional characterization for each 50 layers in agreement with the morphogenesis scenarios of the Junction Chamber. Morphoscopy and mor- 
phometry measures were conducted on numerous levels to identify potential sources of deposits. In a final stage, continuous sequences from the last $1.5 \mathrm{~m}$ of the sediment sequence were extracted using U-Channels. Grainsize measurements with $1 \mathrm{~cm}$ intervals were completed on 190 samples and helped to describe the evolution of the deposition mode in accordance with the enlarge- ment of new conduits. In Jeita lower gallery, the exposed section of deposits is $12 \mathrm{~m}$ thick. 7 units were identified, mapped and described. No samples were extracted from the site for protection reasons but a stratigraphy analysis has been completed along with geomorphological observations inferred from the geomorphological map and cross-sections.

\section{4 - RESULTS}

\subsection{KASSARAT CAVE: STRATIGRAPHY OBSERVATION}

The deposit sequence includes 30 levels. Observation and analysis on the stratigraphy defined three units (e.g. Fig. 6): a) the lower unit, b) the pebbles unit and c) the upper unit.

a- The lower unit is $4 \mathrm{~m}$ thick and comprises 20 levels mostly, composed of coarse and fine sand particles and displaying different texture than the upper unit levels: Most sand levels contains heterogeneous elements displayed as pockets containing clay or angular and chert debris (> $2 \mathrm{~mm}$ ) (e.g. S17, S10, S8). Most layers display a wavy bedding structure. The bedding surfaces are though highly disrupted (e.g. S3 S4, S8, S9, S10 and S11). It could refer either to an erosion of the bedding surface leaving sole markings along the surface after each deposition phase (Collinson and Thompson 1982), or refer to slump structures, a common deformation of the bedding resulting from movement and displacement of unconsolidated or semi-consolidated sediment, mainly under the influence of gravity. Slump structures of the beddings are identified in levels S2, S3, S8 and S9 due to small synsedimentary faults (Chamley 1987). Slump curves could be identified in S14 and S15 levels.

b- The pebbles unit is 30 to $40 \mathrm{~cm}$ thick (e.g. Fig 6) and comprises pebbles set randomly in a sand matrix. Most pebbles are slanted towards the ceiling collapse area (e.g. Fig. 2) and thus indicating a flow direction towards this sector. Lithological composition of the unit indicates $66 \%$ of sandstone pebbles and $34 \%$ of limestone pebbles. Most pebbles size ranges from 20 to $80 \mathrm{~cm}$ in diameter with a roundness mean of 400 according to Cailleux \& Tricart (1959) chart.

c- The upper unit is $162 \mathrm{~cm}$ thick. It is covered by flowstone and includes 10 nearly horizontal bed layers structure with an alternating sand/clay composition. Contact surfaces between layers are horizontal rarely disturbed. Thickness of silt and clay levels (S29; S26) increase as we reach the top of the sequence. The S25 sand level comprises several horizontal sub-levels with dispatched lenses of clay. Sand layers are thicker in the lower part of the unit (S21, S23, S24). Levels S24 and S25 (127 cm depth) comprise calcite incursions. Microscopic observation of sand and clay layers in S20, S21 and S29 show high percentage of quartz, argillites and oxides. Mica and zircon minerals are also observed in level S20. Morphometry analysis of the roundness of quartz minerals indicates a high proportion of rounded particles in S20, S24 and S28 levels.

\subsubsection{GRAIN-SIZE AND STATISTICAL ANALYSIS}

Grain-size and statistical analysis identified several aspects of the flow dynamics.

Analysis of curves (e.g. Fig. 6-C) shows a high percentage of sand $(>80 \%)$ in the lower unit. The particle size distribution varies mainly between 300 and $500 \mu \mathrm{m}$. High peak values are noted in the S2 level (I22) S8 (X5) and S17 (D11) between 600 and $700 \mu \mathrm{m}$. The curves are mostly unimodal (e.g. Fig. 6-D). Mode and mean particle size curves show a decreasing trend from lower level (I22) to the upper level (D13). Statistical analysis shows that most levels present a well sorting index $(1.5<$ So $<2)$ and positive skewness values $(0.5<\mathrm{Sk}<1)$ that generally tend to 1 (e.g. Fig. 6-H).

In the Upper unit, levels S20, S22, S25, S26 and S29 comprise more fine particles than those of the lower unit, with a composition of 20 to $40 \%$ of silt and clay particles in most levels. The grain-size distribution ranges between 50 and $300 \mu \mathrm{m}$. Average particle-size values of sand deposits range between 200 and $300 \mu \mathrm{m}$ and 50 to $100 \mu \mathrm{m}$ for silt levels. Curves of the particle distribution are mostly multimodal, indicating that several thin sub-layers compose the identified layers. The variations in the composition of layers are much more significant in the upper unit. This is defined by rapid changes of mean size and mode curves. Rapid variations are also shown in the curves of the statistical parameters: Well-sorted particles are observed in sand 


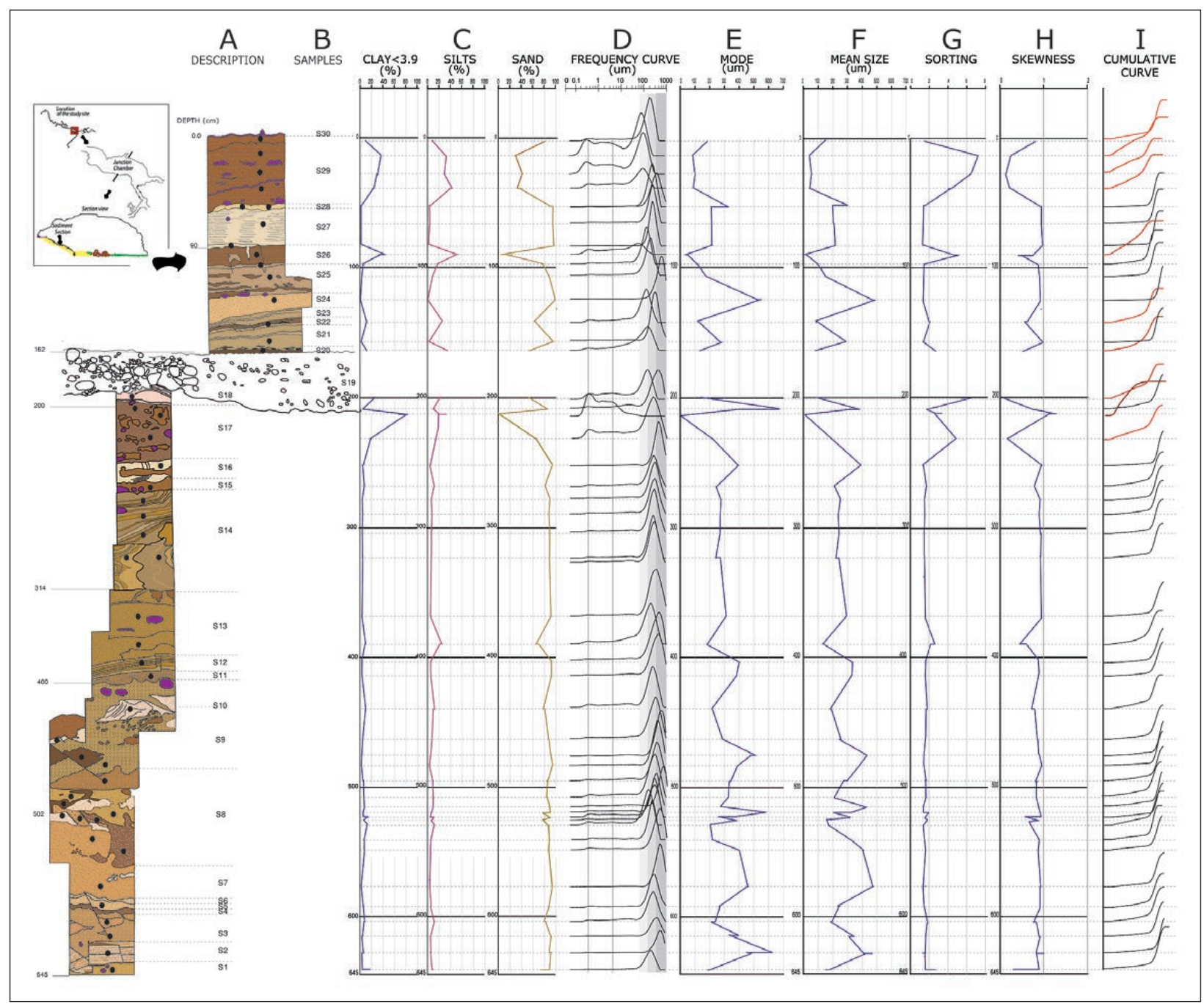

Fig. 6: a synthetic log of the deposit sequence and the grain-size analysis on the 50 samples extracted from the lower and the upper unit of the Junction Chamber in Kassarat cave. Statistical analysis parameters are referenced as: $A=$ Description; $B=S a m p l e s ; C=C o m p o s i-$ tion of clay/silt/sand; $D=$ Frequency curve; $E=$ Mode; $F=$ Mean-size; $G=$ Sorting; $H=$ Skewness; $I=$ Cumulative curves.

levels (So 2) and poorly sorted particles (e.g. Fig. 6-G) in silt and clay levels $(2<$ So $<7)$. Skewness values also vary between $(0<\mathrm{Sk}<1)$.

Crossover analysis between statistical parameters $\left(\mathrm{S}_{\mathrm{o}} ; \mathrm{S}^{\mathrm{k}} ; \mathrm{Md}\right.$ and $\mathrm{C} 99$ percentile) provides indicators of hydraulic conditions under which sediments were deposited (Passega1964; Folk 1980; Chamley 1987). The comparison between sorting and skewness values showed mainly two different fields that infer different types of currents (e.g. Fig. 6-I):

The first field (e.g. Fig. 7A) comprises fine to coarse sand particles from the lower unit, which are well sorted with a medium to high asymmetry. Some particles of the upper unit (C11-C12 levels) are also included. The second field (e.g. Fig. 7A) comprises silt particles mainly from the upper unit. They are poorly sorted with a medi- um to low asymmetry. In order to confirm the flow type, the samples were plotted at CM diagrams (e.g. Fig. 7B) proposed by (Passega1964). Almost all the samples (C: 1st percentile of the cumulative grain size and $\mathrm{M}$ : mean) are plotted near the SR field and in the QR field. The SR field suggests transportation under a graded suspension regime, which correspond to the overflow regime suggested in Fig. 7A. The field QR characterizes a transportation regime by turbidity currents, which correspond to the stream flows suggested in Fig. 7A.

Statistical analysis is in agreement with the general stratigraphy observation on the Kassarat sedimentary sequence. Levels of lower unit were mainly deposited in a turbulent environment with regular but rapid flows. Changes in the hydraulic conditions occurred during the deposition of the upper levels when fluctuations between 


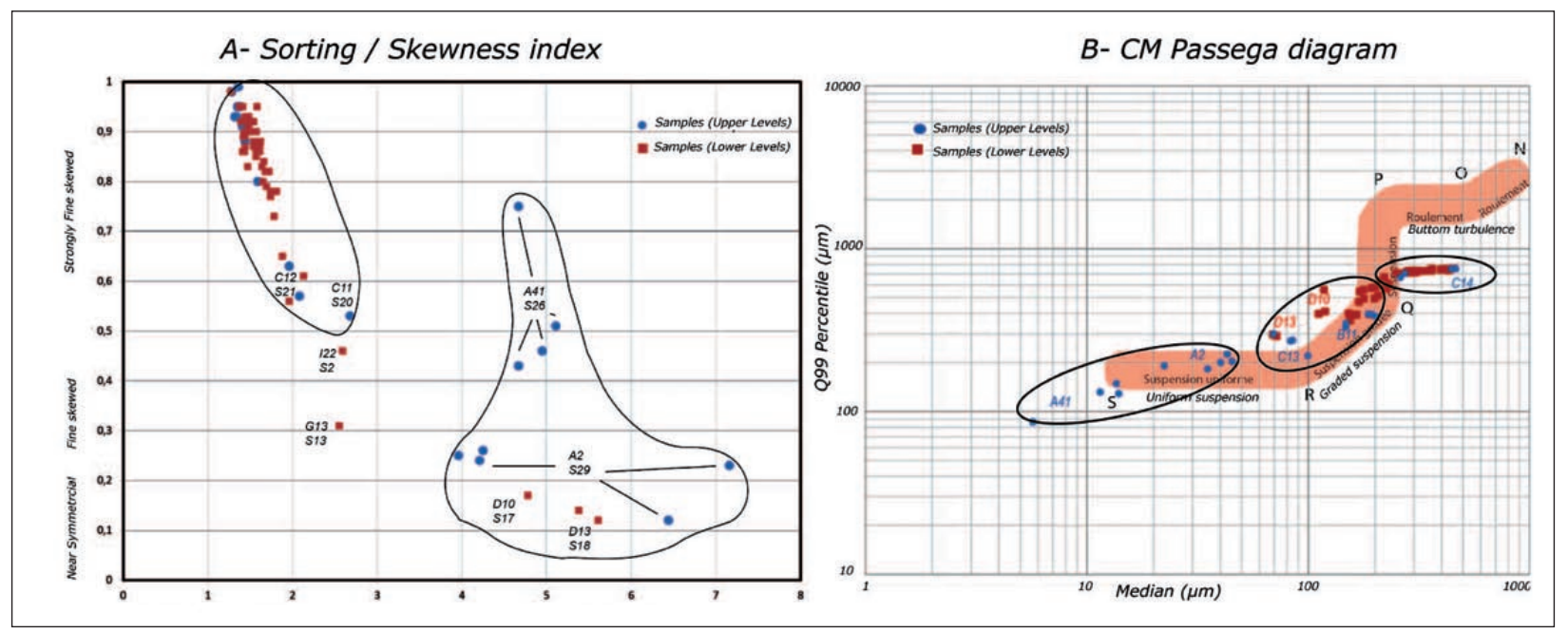

Fig. 7: Statistical analysis on grain-size parameters shows two distinctive fields characterizing the hydraulic conditions under which sediments were deposited in the Junction Chamber. The comparison between the sorting and skewness values (A) and between median and the percentile $(B)$ showed mainly two different fields that infer different types of currents.

regular flows and overflow circulation deposited alternately sand and silt layers.

\subsection{JEITA CAVE: GEOMORPHOLOGY AND STRATIGRAPHY OBSERVATION}

The Entrance Chamber in Jeita lower cave at $62 \mathrm{~m}$ a.s.l. is an enlarged gallery located at the nearest point to the talweg of Kalb River (e.g. Fig. 4). The complex history of the sediment trapping is related to a reorganization of flows based on episodes of alluviation from the inner river as well as from the Kalb River interspersed by collapse events. The Entrance Chamber was considered to be alluviation a paleo-outlet for Jeita River (Hakim 1972) and that the alluviation from different sources forced the river to abandon the outlet at the Entrance Chamber and form a new passage to the present outlet located further downstream at $60 \mathrm{~m}$ a.s.l. (e.g. Fig. 4). It is not clear at this stage if this small altitudinal dif- ference between the Entrance Chamber and the present outlet implies that Jeita river had both outlets that functionned simultaneously or diachronically due to alluviation processes.

The spatial distribution of the fillings in the Entrance Chamber indicates different levels of pebbles, gravel and sand deposits that remained after the excavation of the site. The deposits described herein are located in the southern sector (e.g. Fig. 4) of the Chamber (e.g. Fig. 5A). The northern sector comprises fallen blocks of several meters in length (e.g. Fig. 8A). Blocks from the ceiling lie on disrupted and heterogeneous mixture of fine particles, pebbles and gravel bending over the broken flowstone (e.g. Fig. 8A). The deposit sequence (e.g. Fig $8 \mathrm{~B}$ and Fig. 9) indicate 8 levels described from the bottom to the top of the deposit sequence:

At the base of the sequence, (N1) level comprises 60 $\mathrm{cm}$ of fine sand particles. The (N2) level comprises $80 \mathrm{~cm}$
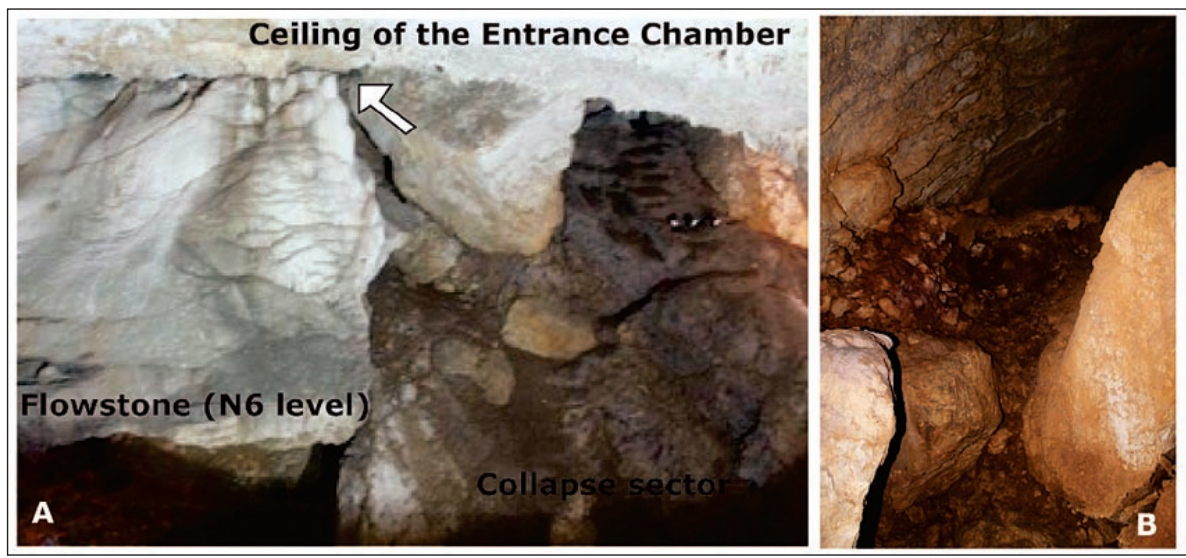

Fig. 8: Photo (A) show the contact between the collapsed blocks and the broken flowstone covering the deposits levels underneath. The white arrow shows the location of the photo (B) on the topmost part of the collapse sector and behind the block. Photo (B) shows flowstone covering pebbles, gravel and fine grained-sediments between the fallen blocks from the ceiling. This level is indicated as N8 in the general section (Photos by Safi J.) 


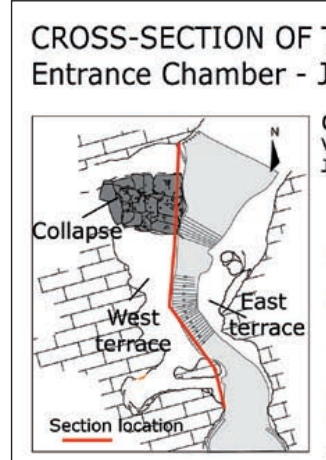

THE DEPOSITS AND SYNTHETIC LOG

Jeita Cave (Lower Gallery)

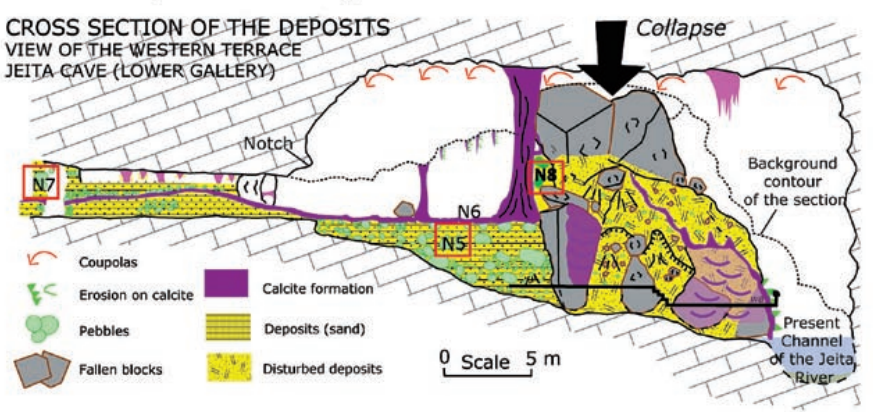

OBSERVED SECTIONS
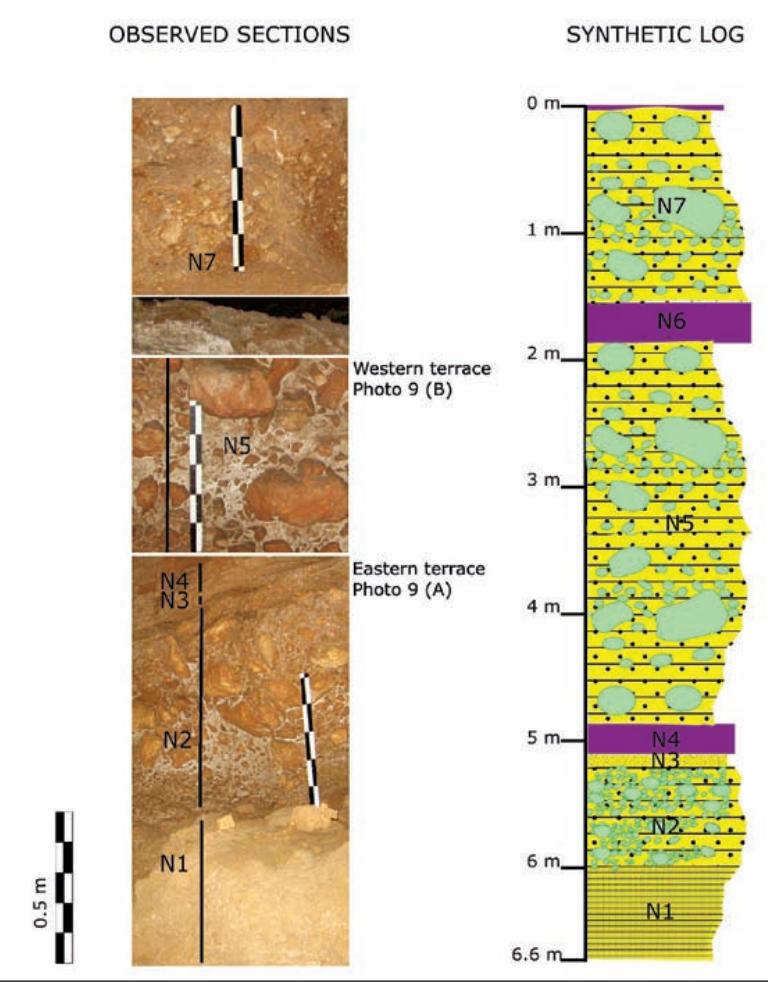

thick of pebbles and gravels covered with a fine red slit level of few centimeters thick (N3). The flowstone level (N4) of $30 \mathrm{~cm}$ thick with a horizontal dip is shown only in the eastern terrace (e.g. Fig. 9-A)

The most remarkable level (N5) comprises $3 \mathrm{~m}$ of pebbles with diverse shape and sizes: small pebbles with a size ranging from 4 to $20 \mathrm{~cm}$ and large pebbles with a size ranging from 25 to $50 \mathrm{~cm}$ and exceptionally few blocks reach $1 \mathrm{~m}$ in length are set randomly in a sand matrix.

The second level (N1) is located in the Entrance Chamber and the Collapse sector (e.g. Fig.1 Jeita map). It is composed by $1.5 \mathrm{~m}$ of pebbles included in a matrix of coarse sand particles. Pebbles sizes range mainly from 4 to $10 \mathrm{~cm}$ and reaches $30 \mathrm{~cm}$ for some. The third level (N2) corresponds to the flowstone of 40 to $60 \mathrm{~cm}$ thick
Fig. 9: The spatial configuration of the sedimentary sequence in the Entrance gallery (Jeita cave) comprises the deposits unit in the cave section and photos corresponding to each level represented in the log. Qualitative indicators are proposed for the evolution of flow velocity. The red box in the cross section show the exact location of the photos for the N5 and the N7 levels. The N8 section is indicated herein by a red box and refers to photo (B) in Fig. 8. and dipping to the Northwest towards the interior of the cave.

The last level (N8) comprises pebbles and angular debris covered with a thin flowstone and located only in the Collapse sector, between the fallen blocks and the broken flowstone of the western terrace (e.g. Fig. 8B).

The morphological analysis in the Entrance Chamber helped to link the successive deposition events with the gemorphological context. Two notches are identified at $67 \mathrm{~m}$ and $71 \mathrm{~m}$ a.s.l. The highest notch (e.g. Fig 9) corresponds to the N8 level located between the fallen blocks and the flowstone and higher than the entrance level (e.g. Fig. 9-cross-section). The spatial distribution of (N8) level would refer to a deposition phase after a collapse event of blocks from the ceiling and covered most of the (N7) level with pebbles and gravel. Pebbles 
distribution in level N2, N5 and N7 show no beddings but display different size. The N5 level has the largest pebbles comparing to the N2 and N7 levels. Along the ceiling, various stalactites display erosion features (small scallops) and contain sand and small pebbles incursions.

\section{5 - DISCUSSION}

The sediment analysis in the Junction Chamber as well as the preliminary analysis of the Entrance Chamber in Jeita lower level helped in reconstituting the hydrodynamic stages of flow readjustments in accordance with the geomorphology features of each site. The significances of water flows variability and the threshold effect detected in the sedimentary analysis are discussed herein as indications to distinguish local effects of sediment trapping from external environmental changes.

\subsection{RECONSTITUTION OF THE HYDRODYNAMIC STAGES}

\subsubsection{The Junction Chamber-Kassarat cave}

Stratigraphy and statistical analysis of the grain-size distribution combined with the speleogenetic observations identify four hydrodynamic stages (e.g. Fig. 10) describing the readjustment of the Kassarat river flow:

Two major events occurred during the second stage: The volume of deposits accumulated in the site separated flows coming from both sumps. Flows from the southern sump formed a new passage (Capture) to join the main river gallery, downstream of the Junction site (e.g. Fig. 10-stage 2). Similarly, flows of the northern sump excavated a passage through the deposits and flushed out some, through the narrow tubular conduit. However, the width of new passages (the capture and the tubular passage) (e.g. Fig. 12) is not wide enough to contain all the flows during floods. A back-flooding process occurred in the Junction Chamber during each flooding event. The statistical analysis of skewness and sorting indexes (e.g. Fig. 7) indicate a low energy environment where fine deposits could have been transported by overflow with low velocity.

The third stage resumes the adjustment of the conduit width: flooding process remaining active in the site because of the small conduit size (capture), clay and silt particles were progressively deposited on the upper part of the sediment sequence during each flood event. The width of the capture conduit became wide enough after several and successive flood events. Flows from the southern siphon were then totally evacuated during flood event, flushing out what left of the deposits in the southern gallery. These progressive processes resulted a local drop of the water level. The water level of the southern gallery becomes lower $(78 \mathrm{~m})$ than both of the northern sump and the tubular conduit ( $82 \mathrm{~m}$ ) (e.g. Fig. 2).

During last stage, the capture controls the local water level. Flows from the upper siphon are then diverted from the initial direction (NW) and joins flows from the southern siphon (SE). The tubular conduit becomes inactive and both southern and upper sumps flows are evacuated through the capture conduit (e.g. Fig. 10-stage 4).

\subsubsection{The Entrance Chamber - Jeita lower level} The general scheme of the hydraulic conditions during the successive deposition events is described in the Fig. 11. In the plan view, two hypothesis, with and without simultaneous functioning of paleo and present outlets are suggested.

The first phase suggests a deposition of fine particles-size (e.g. Fig. 9- N1 level) by a regular flow regime at the base of the cave section (e.g. Fig. 11-stage 1). The pebbles level (e.g. Fig. 9- N2 level) was then deposited during a rapid event that occurred in a high-energy environment (flows with extremely high velocity) and close to a debris-flow type.

The second phase resume the deposition of fine sand levels (N3) and flowstone of calcite (N4 level) in a low energy environment with a very low flow velocity (e.g. Fig. 11-stage 2).

The third phase (e.g. Fig. 11-stage 3) indicates the deposition of $3 \mathrm{~m}$ of pebbles (Level N5) ranging in length from 4 to $20 \mathrm{~cm}$ and from 25 to $50 \mathrm{~cm}$. Few blocks reach exceptionally $1 \mathrm{~m}$ in length. The size of pebbles in level $\mathrm{N} 5$ is different than the level $\mathrm{N} 2$ (4 to $10 \mathrm{~cm}$ in length). Larger pebbles in level N5 might have been deposited by high-energy flows coming not only from Jeita River but also from the Kalb River. Since the Kalb talweg is at $100 \mathrm{~m}$ from the Entrance Chamber, the N5 level might be deposited, during an extreme flood event, by external flows that penetrated in the cave system from the Exit 1 (e.g. Fig. 11, stage 3 ).

The fourth phase (e.g. Fig. 11, stage 4) is radically different from the former stage during which flooding occurred in Jeita lower level. A thick flowstone is deposited during the fourth phase, indicating thus a passage 


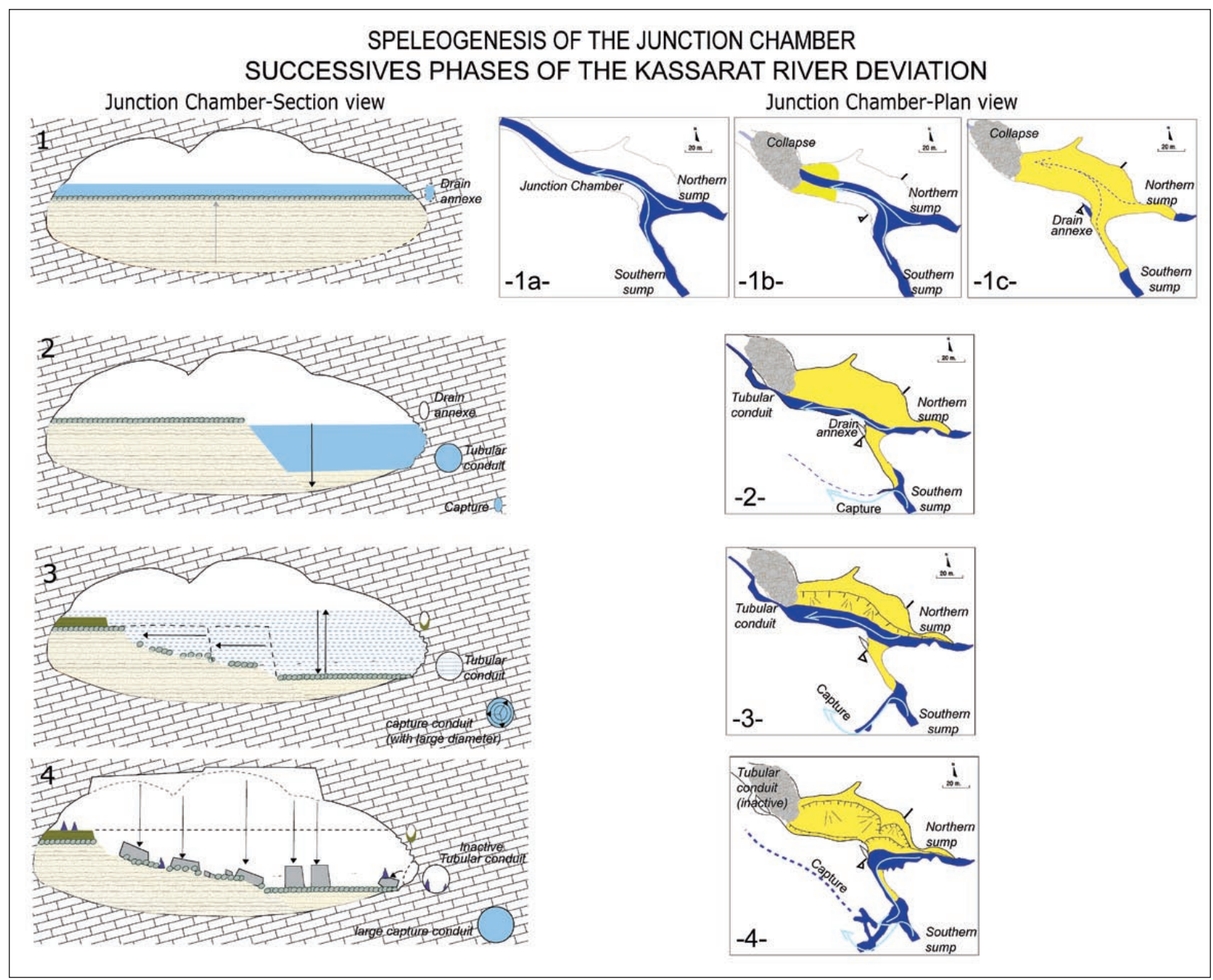

Fig. 10: Speleogenesis scenarios of the Junction Chamber (Kassarat cave) propose four different stages of deposit accumulation and flux adjustment presented in a section view and in plan-view. The first stage of sediment infilling begins when the ceiling collapse obstructed the normal passage of flows. Fine-grained deposits fill, then the Junction gallery as well as some parts of the northern and southern conduits. Sediments reach up to $12 \mathrm{~m}$ height and lead to a full obstruction of this site. Channel flow type turns to pipe-full flow regime leading to nearly phreatic conditions under which the erosion of the ceiling and high small conduits were formed (e.g. Fig. 10-stage 1, drain annexe). The values of both skewness and sorting indexes (e.g. Fig. 7) imply an environment of deposition under high turbulence conditions. Sediments of the lower unit and some of the upper unit could have been transported by regular stream flows with moderate to high velocity.

from epi-phreatic to vadose environment in Jeita lower level. Flowstone as well as stalagmites, columns and stalactites were then formed. Flows of Jeita River were reduced radically in the cave section and circulated at the bottom of the cave section. This would explain the calcite deposition at a higher level of the cave section while Jeita river circulated under the N6 level.

The collapse process occurred lately (e.g. Fig. 11, stage 5), during the fifth phase and disrupted the deposits series, increasing thus the volume of debris accumulated on the site. The collapsed blocks formed then a form of partial blockage (e.g. Fig. 8A) to water flows and protected the accumulated deposits located in the southern side of the cave section.

The ceiling collapse triggered, during the sixth phase, a local effect during which Jeita flows were driven to circulate (e.g. Fig. 11, stage 6) at the top of the cave section, creating thus cupolas at the ceiling and eroding the stalactites (Nehme 2013). The N7 and especially the N8 level deposited on the topmost part of the ceiling collapse sector sealed the Exit 1. The N8 level corresponds with the altitude of the highest notch (Fig. 9) and both are higher than the altitudinal level of Exit 1. The deposits of the latter level come mainly form Jeita flows. 


\section{SECTION VIEW OF THE ENTRANCE CHAMBER}
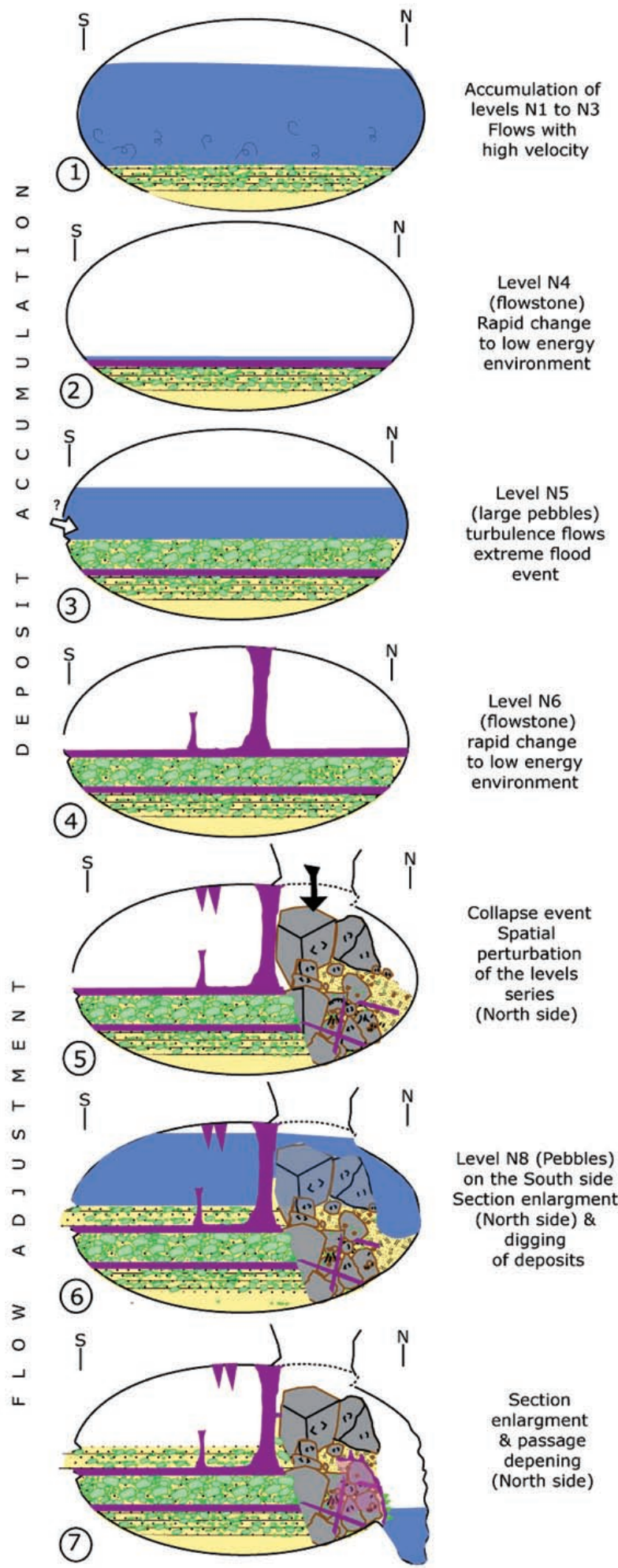

PLAN VIEW OF THE ENTRANCE CHAMBER
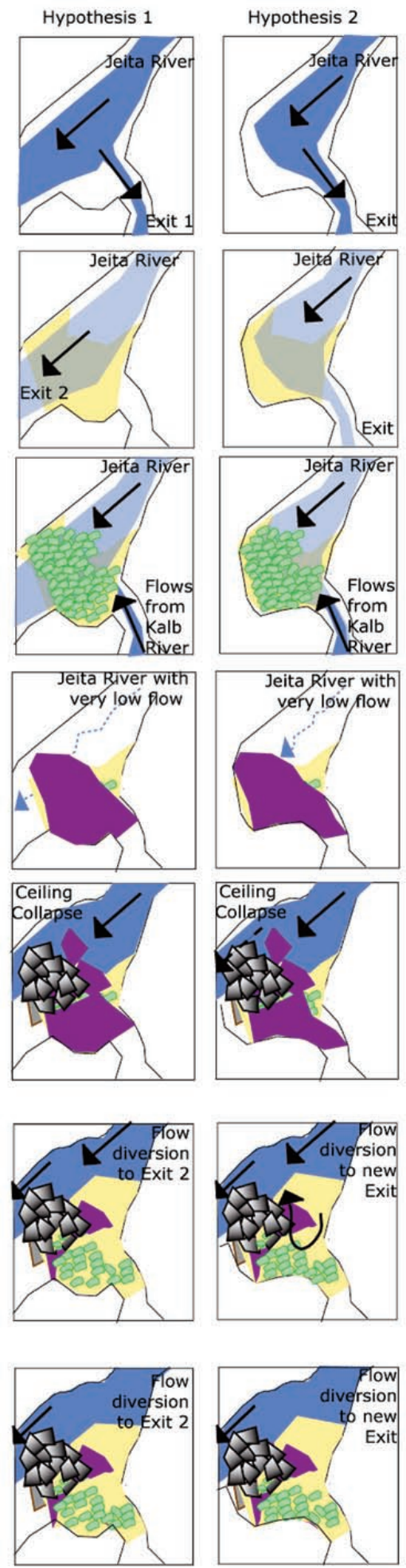

Fig.11: The speleogenetic evolution of the sediment trap in the Entrance gallery (Jeita lower Cave). The first four stages highlight the various accumulation episodes. The last three stages describe the effect of the collapse on the adjustment of flows and the cave-section enlargement. 

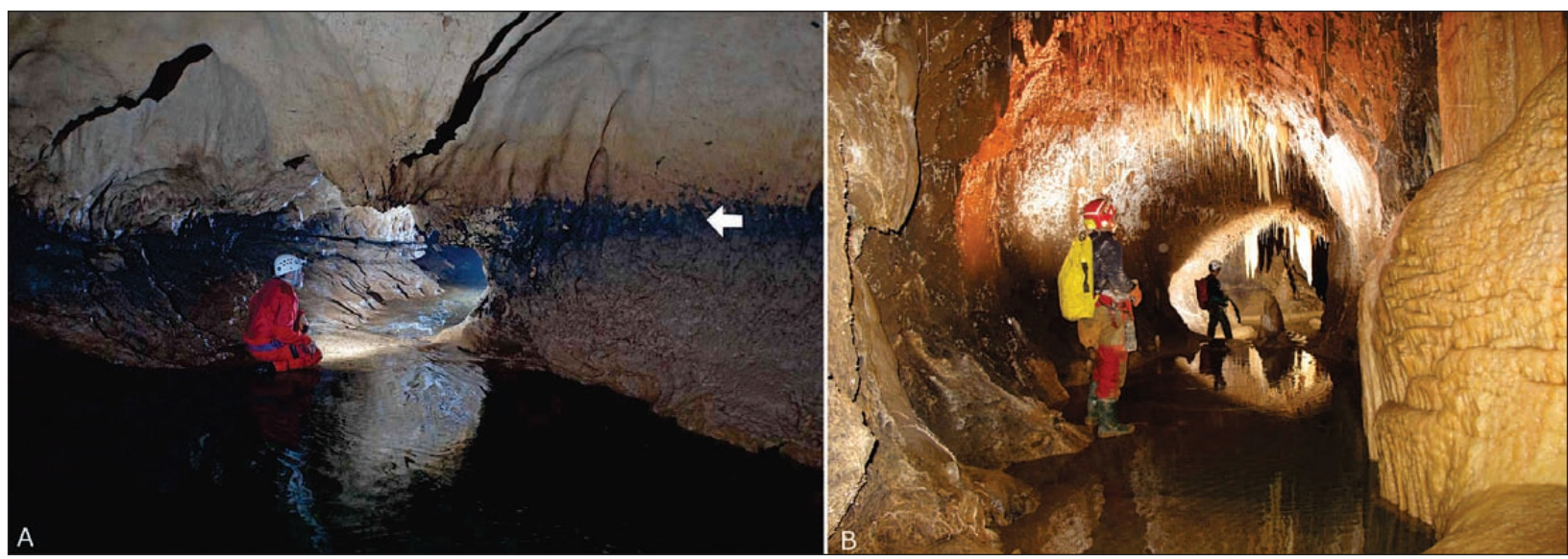

Fig. 12: Photo (A) shows the section of the capture in the Junction Chamber. The white arrow indicates the flow level during high discharge periods. In the present time, all the flow is drained by the capture conduit. Photo (B) is the tubular conduit located at the base of the collapse sector in the Junction Chamber. Both conduits (Photos A and B) present a section diameter with narrower widths comparing to the Junction Chamber Section (see fig. 2).

The new configuration of deposits with the collapse of the ceiling decreased the available volume for water circulation in the cave section and forced Jeita River to deepen a new passage by incising the disrupted sediments in the northern side of the cave section (e.g. Fig. 11, stage 7). Morphological sections on the site indicate numerous scallops with diverse shape and sizes, located on the north side of the cave section (Nehme 2013).

\subsection{VARIABILITY OF WATER FLOWS AND LOCAL WATER LEVELS.}

Cave passages morphology and collapse affect considerably the spatial and temporal distribution of sediments creating therefore, local effects that control the location of newly formed passages. In Kassarat cave, the collapse created a form of blockage to water circulation and triggered (e.g. Fig. 10) a whole range of process that lead to the present spatial configuration. Such blockage contributed in rising water level in the cave section increasing therefore pipe-full flows in the main passage. Flow velocity decreasing rapidly in the Junction Chamber, led to the ponding of water behind the collapse. Such flux adjustments triggered the alluvium process aggrading, therefore the volume of deposit behind the blockage. In Jeita cave, allocthonous sediments were deposited first in the southern part of the site where the passage cross-section is more expanded. The collapse occurring after several deposition stages, contributed in creating a form of blockage increasing therefore the volume of sediments with the deposition of new levels on the collapsed blocks. The new spatial distribution of the deposits leads to the formation of new passages. Flows were driven to circulate in specified locations in newly formed conduits located preferentially at the edges of the cave-section in Jeita (narrow passage) and in Kassarat cave (tubular conduit) or upstream to the blockage sector (the capture conduit in the southern gallery).

The younger passages show in both sites narrower widths comparing to those of the older- passages: in Jeita cave, the regular width of the lower active gallery ranges from 8 to $13 \mathrm{~m}$ (Karkabi 1963). The passages located after the sediment trap display narrower sections with a width ranging from 3.6 to $6.6 \mathrm{~m}$ (Karkabi 1963). In Kassarat cave, the width of passages in the main canyon ranges from 10 to $13 \mathrm{~m}$ and 30 to $40 \mathrm{~m}$ in the Junction Chamber while the width of the younger passages (e.g. Fig. 12) formed during the collapse and the alluvium process varies from 3 to $6 \mathrm{~m}$. In both Kassarat and Jeita caves, new passages were also deepened few meters less than the altitudinal levels of the main active cave passages (e.g. Fig. 2 and 4). The decrease in the passages width and their altitudinal levels would be related to a decrease in the flow amount. This would infer to less water inputs into the cave system or to a local reorganization of fluxes controlled by the drop of the water base level.

Study of sedimentary sequences show, in some case, variations in types of deposits. Continuous deposit variations depends generally on flow conditions that involve several local and regional parameters. The main factor concerning the deposit variation is the flow rate and its capacity in transporting such particles sizes (pebble, coarse sand, silt). Flow rates are mainly conditioned by the passage morphology but depend also on either the cave system is at base flow or flood flow when extreme climate conditions occur (White 2007). Variations on types of deposits are observed in the sequence of Jeita cave and less in the Kassarat cave. In the latter site, only level S19 


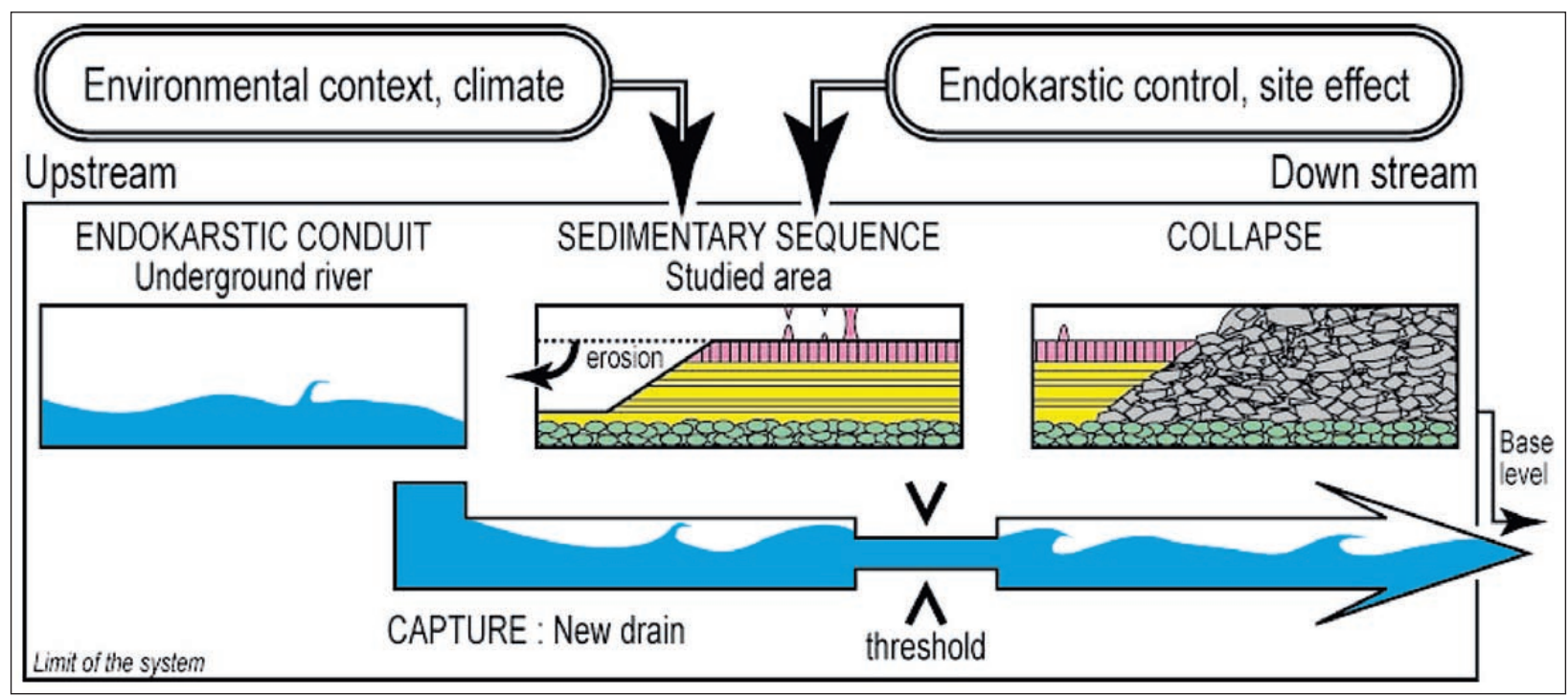

Fig. 13: A synthetic model shows the readjustments of flows in cave systems when deposits fill in a cave passage. Flows and sediment particles imputed in the system are firstly conditioned by external factors (the environmental context and the climate). Considering that flows are confined to a certain conduit size, flow velocity and range of particles-size deposited in the cave are conditioned by the accumulation of former deposits and new formed conduits (capture) to contain the flows diverted from the blockage area. The threshold (conduit morphometry) constrains flow velocity during each flood event.

formed by coarse gravel and pebbles with no bedding, is set disparately from other lower and upper fine sand and silt bedded levels. The S19 level was deposited by debris flows related mainly to an extreme flood event, unlikely to the lower levels deposited by regular stream flows and to the upper levels related to over flows. Even though variations are observed between silt and fine sand levels in the upper unit, but this slight grain-size change would be more related to local effect controlled by the capture width than to external environmental changes. Similar analysis on sediments in Choranche caves, France infer to the effect of the conduit size on the slight grain-size change in the Chevaline sumps (Lignier et al. 2012).

The deposit sequence of Jeita cave indicates variations in type of deposits, ranging from pebbles (N2, N5, N7, N8), to thick flowstone (N4, N6). This infers to changes in the hydrological regime during the deposition: the pebbles deposited by debris flow could be more related to external events such as floods (Dogwiler and Wicks 2004). Thick flowstone levels would be related more to low energy flows, due probably to less water inputs in the cave system. Though, it could also result from flows readjustments induced by the lowering of water base level and creating consequently temporary Vadose conditions for calcite deposition.

\subsection{THRESHOLD EFFECT}

On of the main local effects demonstrated by the grainsize analysis is the result of thresholds on deposit accumulation. This is largely documented in karst studies on cave sediments (Jaillet 2005; Lignier 2001; Perroux 2005), demonstrating the influence of passages width in delaying transport and deposition of particles of a single flow event in several parts of the cave system. Passage width controls the sediment signal (type of grain-size, thickness of deposit level) through a piston flow effect when particles are transported between several sediment traps. Comparable studies were documented in hydrological studies highlighting the piston flow of stored water through springs prior to the arrival of storm water (Dreiss 1989; Herman et al. 2008). In Kassarat cave, sediment analysis and the observation of the speleogenic context helped to confirm the enlargement of the new passage (capture conduit), which had a threshold effect on the types of deposits in the Junction Chamber:

Even though the collapse triggered alluviation in both sites, other processes contributed in the modification of flow rate and consequently the depositional environment: i) the reduction of the flow area, ii) the flow evacuation from new conduits that were not wide enough to evacuate all the flow, leading eventually to an overflow in the Junction Chamber. This latter local effect required more accurate grain-size analysis on the upper unit. New particle size measurements were made in $1 \mathrm{~cm}$ intervals and results (Nehme et al. 2013) showed a general decrease of the mean size of particles, despite the irregular particle composition of several levels. This general decrease in the flow rate is conditionned by the width of the new passage from which the water coming from both southern and northern sumps is evacuated. 
The enlargement of the passage first contained turbulent flows transporting coarse sand particles and the over flow occurring in the Junction chamber lead to the deposition of fine-grained particles in the upper level of the sequence. The progressive widening of the passage (Capture) lead to a progressive decrease of the mean size of particles in the upper levels of the sequence, controlling therefore the over flow process.

In the sediment trap of Jeita cave, the threshold effect was triggered by the ceiling collapse leading to sev- eral successive processus: i) deposition of the N8 level by the Jeita river on the topmost part of the section, ii) reduction of the section width and iii) depening of a small passage on the northern side on the Chamber. Yet, the Kalb river participated in filling the Entrance Chamber (N5 level) in the lower section but the topmost part of the sediment section is of inner origin (from the underground river) due to the position of this topmost part above the altitude of the touristic entrance $( \pm 73 \mathrm{~m})$.

\section{CONCLUSION}

Study of both sediments traps associated to collapse reveals interesting information on readjustments and evolution of flows within cave systems. Grain-size analysis of cave deposits helped to give some indications on the paleohydrological context during the depositional process. In sites located near cave outputs, the geomorphological approach combined with the stratigraphy analysis helped in discerning levels deposited by underground rivers from those of outer origin. In this paper, the study of both sediments traps in Jeita and Kassarat caves demonstrated the effect of local parameters, such as the threshold effect generated by width of passages, volume of collapse and local water level fluctuations on the deposition process (e.g. Fig. 13). Deposition in cave systems depends on flow rates that involve, nevertheless both local and regional parameters. The environmental signal interpreted in sedimentary sequences by the grain-size variability could be, therefore reduced. The local context of the depositional process must be taken into consideration before relating sediment inputs in caves to external environmental change.

\section{ACKNOWLEDGMENTS}

The analysis and sampling on sites was undertaken under the authorizations of the ministries of Tourism, Environment of Lebanon and the Department of water resources of Mount-Lebanon. We thank Dr. Nabil Haddad, director of MAPAS (operator of Jeita Grotto showcave) for his continuous support and generous hospitality. Many thanks to B.T.D. (Bureau Technique et Développement) for providing hydrological data on Antelias spring. Finally, we're thankful to Pierre-Charles Gérard and A.L.E.S. cavers-Association Libanaise d'Etudes Spéléologiques for providing technical support to complete sampling during field trips. The authors are grateful to the anonymous referees for improving this paper.

\section{REFERENCES}

Abdul-Nour, H., 2004: Les cavités de l'endokarst du Liban.- Spéléorient, 4, 116-128.

Berger, G.W., Perez-Gonzalez, A., Carbonell, E., Arsuaga, J.L., Bermudez De Castro, J. \& T. Ku, 2008: Luminescence chronology of cave sediments at the Atapuerca paleoanthropological site, Spain.- Journal of Human Evolution, 55, 300-311.
Bogli, A., 1980: Karst hydrology and physical speleology.Springer-Verlag, pp. 294, Berlin.

Bosák, P., Pruner, P. \& J. Kadlec, 2003: Magnetostratigraphy of Cave Sediments: Application and Limits.Studia Geophysica et Geodaetica, 47, 2, 301-330. 
Bull, P.A., 1980: Towards a reconstruction of time-scales and palaeoenvironments from cave sediment studies.- In: Cullingford, R.A. et al. (eds.) Timescales in geomorphology. John Wiley, pp. 177-187, London.

Cailleux, A. \& J., Tricart, 1965: Initiation à létude des sables et des galets.- Centre de la Documentation Universitaire, Tome I, II et III, pp. 194, Paris.

Chamley, H., 1987: Sédimentologie.- Edition Dunod, pp. 175 , Paris.

Delannoy, J-J., Gauchon, Ch., Hoblea, F., Jaillet, S., Maire, R., Perrette, Y., Perroux, A.-S., Ployon, E. \& N. Vanara, 2009: Le karst : des archives paléogéographiques aux indicateurs de l'environnement.Géomorphologie : relief, processus et environnement, 2009, 2, 83-94.

De Waele, J., Gutiérrez, F., Parise, M. \& L. Plan, 2011: Geomorphology and natural hazards In karst areas: A review.- Geomorphology, 134, 1-8.

Dogwiler, T. \& C.M. Wicks, 2004: Sediment entrainment and transport in fluviokarst systems.- Journal of Hydrology, 295, 163-172.

Doummar, J., 2012: Identification of indicator parameters for the quantitative assessment of vulnerability in karst aquifers.- $\mathrm{PhD}$ thesis, Göttingen University Göttingen, pp. 116.

Dreiss, S.J., 1989: Regional scale transport in a karst aquifer; 1, Component separation of spring flow hydrographs.- Water Resources Research, 25, 117-125.

Dubertret, L., 1951: Carte géologique du Liban: Beyrouth 1/50000e. Ministère des travaux publics, Beirut, Lebanon.

Dubertret, L., 1975: Introduction à la carte géologique au 1/50000 du Liban.- Notes et mémoires sur le Moyen-Orient, 23, 345-403.

Farrant, A.R., Smart, P.L., Whitaker, F.F., \& D.H. Tarling, 1995: Long-term Quaternary uplift rates inferred from limestone caves in Sarawak, Malaysia.- Geology, 23, 357-360.

Farrant, A., \& P. Smart, 2011: Role of sediment in speleogenesis; sedimentation and paragenesis.- Geomorphology, 134, 79-93.

Folk, R.L., 1980: The Petrology of Sedimentary Rocks.Hemphill Publishing Company, pp. 182 pages, Austin, Texas.

Ford, D.C. \& P., Williams, 2007: Karst hydrogeology and geomorphology.- Wiley, United Kingdom, pp.562, Chichester.

Granger, D.E., Fabel, D. \& A.N., Palmer, 2001: Pliocene-Pleistocene incision of the Green River, Kentucky, determined from radioactive decay of cosmogenic 26Al and 10Be in Mammoth Cave sediments.- Geological Society of America Bulletin, $113,825-836$.
Gedeon, M., 1999: Structural analysis of latitudinal fault in the Mount-Lebanon north of Beirut: their kinematics and their role in the tectonic evolution of Lebanon.- Master thesis, American University of Beirut, pp. 245.

Gillieson, D., 1986: Cave sedimentation in the New Guinea highlands.- Earth Surface Processes and Landforms, 11, 533-543.

Hakim B., 1975: Recherches d'hydrologie et de morphologie karstiques au Liban central : bassins du Nahr el-Kelb, Nahr Ibrahim et leurs confins.- PhD thesis, Université Aix-en-Provence France, pp. 158.

Hakim, B., \& S. Karkabi, 1988: Coloration du gouffre de Faouar Dara et de la grotte des Kessarat.- Al- OuateOuate, Spéléo Club du Liban, 3, 18-31.

Hakim B., 1985: Recherche hydrologiques et hydro chimiques sur quelques karsts méditerranéens: Liban, Syrie, Maroc.- PhD thesis, Lebanese University Beirut, pp. 700.

Häuselmann, A.D., Häuselmann, P. \& B.P. Onac, 2010: Speleogenesis and deposition of sediments in Cioclovina Uscată Cave, Șureanu Mountains, Romania.- Environmental Earth Sciences, 61, 1561-1571.

Herman, E., Toran, L., \& W., White, 2008 : Threshold events in spring discharge: Evidence from sediment and continuous water level measurement.- Journal of Hydrology, 351, 98- 106.

Jaillet, S., 2005: Le barrois et son karst couvert.- Karstologia Mémoires, 12, pp. 335.

Jameson, R.A., 1991: Concept and classification of cave breakdown: An analysis of patterns of collapse in Friars Hole Cave System, West Virginia.- In: Kastning, E.H., \& K.M. Kastning (eds.) Appalachian Karst. National Speleological Society, pp. 35-44, Huntsville, Alabama.

Karanouh, R., Bou jawdeh, I., Comaty, A., \& J., Tawk, 2004: Mgharet el Kessarat cave system.- Al-OuateOuate, 13, map annex.

Karkabi, S., 1963: Relevé topographique de la rivière souterraine de Jiita au 1/500.- Office des eaux de Beyrouth, 3 maps.

Karkabi, S., 1990: Cinquantenaire de la spéléologie libanaise.- Al-Ouate-Ouate, Spéléo Club du Liban, 5, $1-136$.

Labaky, W., 1998: A hydrogeological and environmental assessment of the Fouar Antelias catchment.- Master thesis in Science, American University of Beirut, pp. 132.

Lignier, V., 2001: Les sédiments lacustres et l'enregistrement de la paléosismicité.- $\mathrm{PhD}$ thesis, Université de Savoie France, pp. 381. 
Lignier, V., Jaillet, S., Perroux, A.-S., Thomas, M., Malet, E., Deves, G., Morel, L. \& J.J. Delannoy, 2012: Dynamique sedimentaire et effets de site en zone noyee du karst: l'exemple du siphon de Chevaline (Grotte de Choranche, Vercors, France).- Karstologia, 60, 23-44.

Martini, I., 2011: Cave clastic sediments and implications for speleogenesis: New insights from the Mugnano Cave (Montagnola Senese, Northern Apennines, Italy).- Geomorphology, 134, 452-460.

Metni, M. \& F.H. Nader, 2005: Mgharet el-Kessarat. History, Morphology and Speleogenesis.- Al-OuateOuate Speleo Club du Liban, 13, 8-13.

Nehme, C., Delannoy, J.-J., Adjizian-Gerard, J. \& J. Hellstrom, 2012: Late Pleistocene evolution of Antelias valley (Lebanon): speleogenic approach applied on Kassarat cave system with implication of U/Th datations records.- In : $20^{\text {th }}$ International karst school of the Karst Research Institute, Classical karst Karst forms and processes, $20^{\text {th }}-23^{\text {th }}$ June 2012, Postojna, Slovénia, ZRC-SAZU, 66-67, Postojna.

Nehme, C., Delannoy, J.-J. , Jaillet, S., Adjizian-Gerard, J., Hellstrom, J., Comaty, T., Arzouni M. \& P., Matta, 2013a : Sedimentary study and U-Th datations contribution in the reconstitution of the Junction Chamber morphodynamic, Kessarat cave, Nabay, Lebanon: A geomorphological approach for palaeohydrological records analysis. In : Filippi M., Bosak P. (Eds) the Proceedings of the 16th International Congress of Speleology, 21 $1^{\text {th }}-28^{\text {th }}$ July 2013, Brno, CZECH SPELEOLOGICAL SOCIETY, Praha, Czech Repbulic, 3, 384-389, Praha.

Nehme, C., Voisin, C., Mariscal, A., Gerard, P.C., Cornou, C., Jabbour-Gedeon, B., Amhaz, S., Salloum, N., Badaro-Saliba, N., Adjizian-Gerard, J. \& J.J. Delannoy, 2013b: The use of passive seismological imaging in speleogenetic studies: an example from Kanaan Cave, Lebanon.- International Journal of Speleology, 42, 2, 97-108.

Nehme, C., 2013c: Apport de l'endokarst dans la reconstitution des paléogéographies et environnements passés du Mont-Liban: le cas des vallées de Nahr Antelias et Nahr el-Kalb.- PhD thesis, Grenoble University France, pp. 450.

Passega, R., 1964: Grain size representation by C/M patterns as a geological tool.- Journal of Sedimentary Petrology, 34, 4, 830-847.

Perroux, A.-S., 2005: Les remplissages détritiques endokarstiques. Contribution méthodologique à la lecture des mémoires paléogéographiques et environnementales: Application aux systèmes karstiques de Choranche (Vercors) et d'Orgnac (Bas-Vivarais).$\mathrm{PhD}$ thesis, Université de Savoie France, pp. 418.
Polk, J.S., Van Beynen, P.E. \& P.P. Reeder, 2007: Late Holocene environmental reconstruction using cave sediments from Belize.- Quaternary Research, 68, 53-63.

Pușcaș, C., Stremtan C.C. \& F. Kristali, 2010: Past surface conditions and speleogenesis as inferred from cave sediments in the Great Cave of Salitrari Mountain (SW Romania).- Studia Universitatis Babeş-Bolyai, Geologia, 55, 2, 51 - 57.

Quinif, Y., 2006: Complex stratigraphic sequences in Belgian caves correlation with climatic changes during the middle, the upper Pleistocene and the Holocene.- Geologica Belgica, 9, 3-4, 231-244.

Renault, P., 1968: Contribution à l'etude des actions mécaniques et sédimentologiques dans la spéleogenèse.- Annales de Spéléologie, 23, 529-596.

Sbai, A., Ek, C., Drouin, Ph., Chirol, B., Ariagno, J.-C., Pelisson, A. \& Y., Quinif, 1995: Les remplissages karstiques de la grotte Sous-les-Sangles: Sédimentologie et évolution spéléomorphologique d'une grotte du Jura méridional (France).- Quaternaire, 6, $1,35-45$.

Saunderson, H.C., 1977: The sliding bed facies in esker sands and gravels: a criterion for full-pipe (tunnel) flow?.- Sedimentology, 24, 623-638.

Sasowsky, I.D., 2007: Clastic sediments in caves - imperfect recorders of processes in karst.- Acta Carsologica, 36, 1, 143-149.

Sweeting, M.M., 1972: Karst landforms.- Macmillan, pp. 362, London.

Walley, C.D., 1998: Some outstanding issues in the geology of Lebanon and their importance in the tectonic evolution of the Levantine région.- Tectonophysics, 298, 37-62.

White, W.B., 1988: Geomorphology and hydrology of karst terrains.- Oxford University Press, pp. 464, New York.

White, E.L. \& W.B., White, 1969: Processes of cavern breakdown.- National Speleological Society Bulletin, 31, 83-96.

White, W.B., 2007: Cave sediments and paleoclimate.Journal of Cave and Karst Studies, 69, 76-93.

Zupan Hajna, N., Pruner, P., Mihevc, A., Schnabl, P. \& P., Bosak, 2008: Cave sediements from the Postojnska-Planinska cave system (Slovenia): Evidence of multi-Phase evolution in epiphreatic zone.- Acta Carsologica, Postojna, 37/1, 68-86. 